\title{
Effect of Vitamin D Supplementation on Patients with Acne Vulgaris: An Intervention Study
}

\author{
Walaa M. Abdelaziz ${ }^{1 *}$, Taghreed M. Farahat ${ }^{1}$, Hala M. Shaheen ${ }^{1}$, Mohamed A. Gaber ${ }^{2}$, Nora A. \\ Kkalil $^{1}$ \\ ${ }^{1}$ Family Medicine Department, Faculty of Medicine, Menoufia University, Egypt \\ ${ }^{2}$ Dermatology and Andrology Department, Faculty of Medicine, Menoufia University, Egypt
}

\begin{abstract}
:
Background: Acne is chronic inflammatory disease with formation of papules, pustules, and nodules. Vitamin-D is fat soluble vitamin with immunomodulatory function, helps reducing inflammation. Objectives: assess frequency of serum vitamin-D deficiency among acne vulgaris patients and the effect of vitamin-D supplementation on acne grading. Method: the study was conducted on two phases, phase I was a cross-sectional study included measuring serum vitamin D level for 80 acne patients attending dermatology clinic at Menoufia University Hospital. Phase II was an interventional case control study where studied acne patients with vitamin-D deficiency (66 patients) were randomly divided into two groups; one group (33 patients) were treated with free Oral vitamin-D 2000IU/ tablet daily for two months in addition to regular acne treatment. The other group (33 patients) received traditional treatment for acne without vitamin-D supplementation and both groups were followed up clinically for two months. Results: frequency of vitamin-D deficiency among studied patients was $82.5 \%$, there was statistically significant relation between vitamin-D deficiency and severity of acne as $27.3 \%$ and $9.1 \%$ of them had grade $3 \& 4$ acne respectively versus $7.1 \%$ and zero $\%$ among acne patients with normal vitamin D. Vitamin-D deficiency is significantly prevalent among female patients (98.4\%), there was significant improvement in acne grading after vitamin-D supplementation. Conclusion: There is a significant relation between vitamin-D deficiency and severity of acne vulgaris and vitamin -D has a good role in management of acne. So. It is recommended to evaluate the serum level of vitamin D in acne patients and provide vitamin D supplementation to vitamin D deficient patients beside topical treatments for acne.
\end{abstract}

Keywords: Acne, Vitamin-D Supplements, Topical Treatment

\section{Introduction:}

Acne Vulgaris is a common skin disorder worldwide, affecting all ages and races, considered as a long term chronic inflammatory disease of the skin. ${ }^{(1)}$ It affects nearly $85 \%$ of adolescents ${ }^{(2)}$ and about $30 \%$ of adults which is known as post- adolescent acne that often occurs in individuals aged 25 years or older particularly women. ${ }^{(3)}$ Acne lesions, which may be papules, pustules, or nodules commonly affecting face, chest and back therefore acne patients may suffer from emotional distress due to its chronicity and potential outcomes which include physical scars and persistent hyperpigmentation. ${ }^{(4)}$
Some medical conditions predispose acne vulgaris like polycystic ovaries (PCO), congenital adrenal hyperplasia and depression. Acne is characterized by pimples, scaly red skin, blackheads, whiteheads, pinheads, and large papules. The most distressing form of acne is called cystic acne, which develops internally beneath the skin, whereas most other forms of acne are more superficial. ${ }^{(5)}$ Although multiple factors contribute to acne development, chronic inflammation is an important mechanism. Several inflammatory mediators such as cytokines, defensins have been identified in acne lesions. ${ }^{(6)}$

*Corresponding author: E-mail: walaalamarleenlara@gmail.com

@ This article is an open access article distributed under the terms and conditions of the Creative Commons Attribution (CC BY) license (http://creativecommons.org/licenses/by/4.0/ 
Vitamin D plays a role in regulating immune system, proliferation, and differentiation of keratinocytes and sebocytes. It has antioxidant and anti-comedogenic properties. ${ }^{(7)}$ So, vitamin D deficiency has a positive role in pathogenesis of acne vulgaris. ${ }^{(8)}$

Vitamin D is fat-soluble substance that is synthesized in human body when the skin is exposed to ultraviolet (UV) light and it can be obtained exogenously through dietary intake. Vitamin D has an important impact on skin health, its deficiency is associated with many dermatological disorders. ${ }^{(9)}$ Acne vulgaris appears to be seasonal, with the winter months seeing the most severe form of disease, however in summer months (when vitamin D levels are higher), there is significant improvement in acne lesions. ${ }^{(10)}$

Vitamin D is considered as antioxidant agent that has positive effect on acne vulgaris. It seems that vitamin $\mathrm{D}$ makes superoxide dismutase (SOD) and glutathione peroxidase (GSH-Px) which were found at lower levels in papulo-pustular cases of acne. ${ }^{(11)}$

Since the antimicrobial role of vitamin $\mathrm{D}$ is the new issue to be raised by many authorities and social cultures and focused on now as a treatment. This study was conducted to highlight the effect of vitamin D supplementation on treating acne patients. The study aimed to assess frequency of serum vitamin-D deficiency among studied acne patients and the effect of vitamin-D supplementation on acne grading.

\section{Methods:}

This study was conducted on acne patients who were recruited from dermatology outpatient clinics, Menoufia University Hospital, Egypt in the time frame from May 2019 to April 2020. The sample size was calculated to be 78 acne patients using Raosoft online sample size calculator with power of $80 \%$, confidence interval of $95 \%$ based on the prevalence of acne vulgaris in adult patients from the previous literatures $(93.2 \%),{ }^{(10)}$ the sample was increased to 90 to compensate for the dropout and data loss.

Ten patients withdrew from the study during the follow up stage and the study was conducted finally on 80 acne vulgaris patients. Based on their previous medical history; certain acne patients were excluded from the study e.g., those with topical or systemic treatment with steroids, diabetes mellitus, thyroid disorders (increased comedogenesis), hepatic enzyme inducers (accelerated vitamin D metabolism), Chronic liver or renal diseases (metabolic disturbances), females with PCO (hyperandrogenism and increased comedogenesis) and acne patients receiving vitamin D or calcium supplementation.

The studied acne patients who accepted to participate in the study and fulfilled the exclusion criteria were selected from a total of 230 acne patients who attended the dermatology clinic during period of data collection. The study was conducted on two phases; the first phase 
was cross-sectional study to assess frequency of vitamin D deficiency among the studied group.

The severity of acne vulgaris was assessed by clinical examination according to: Tutakne (12) grading system for acne which classifies acne vulgaris into four grades as follows: Grade 1: Comedones, occasional papules, Grade 2: Papules, comedones, few pustules (1-3), Grade 3: Predominant pustules $>3$, nodules, abscesses, Grade 4: Mainly cysts, abscesses, widespread scarring.

Blood samples (2 $\mathrm{ml})$ withdrawn once to assess vitamin D level in the studied acne patients after having their consent where normal vitamin D level is > $30 \mathrm{ng} / \mathrm{dl}$, level $20 \mathrm{ng}-30$ $\mathrm{ng} / \mathrm{dl}$ is insufficient, level $<20 \mathrm{ng} / \mathrm{dl}$ is deficient. (13) Then the acne patients with vitamin D deficiency (66 patients) were randomly divided into two groups using computer-based randomization to start the second phase of the study as a case control study. The case group (33 patients) were treated with maintenance dose of free oral vitamin D 2000IU per tablet daily (14) for 2 months besides regular treatments of acne. The control group (33 patients) received traditional treatment for acne vulgaris without vitamin D supplementation. Both groups were followed up clinically after two months.

The control group received vitamin D supplementation after the follow up stage of the study for ethical considerations.Digital photos for acne lesions before and after treatment were obtained from participants after having their written consent.
Data Management: Statistical presentation and analysis of the present study was conducted with SPSS V.20, X2 (Chi 2 test): for comparison between two independent qualitative variables normally distributed. F test: for comparison of two statistical models that have been fitted to a data set, $\mathrm{P}$ value $>0.05$ was considered statistically non-significant, $\mathrm{P}$ value $<0.05$ was considered statistically significant, $\mathrm{P}$ value < 0.001 was considered statistically highly significant.

Ethical consideration: The study was approved by the ethical committee of the Faculty of Medicine, Menoufia University. All participants were volunteers, written consents were taken from patients after explaining the purpose of the study and assuring confidentiality.

\section{Results:}

This study shows that frequency of vitamin D deficiency among the studied acne patients was $82.5 \%$ (Figure 1a). Vitamin D deficiency was significantly more prevalent among female acne patients (98.4\%) (Figure 1b). There was a significant negative correlation between acne grade and serum level of vitamin- D (Figure 2). A statistically significant relationship was found between serum vitamin D level and severity of acne vulgaris as $27.3 \%$ and $9.1 \%$ of vitamin D deficient group had grade $3 \& 4$ acne respectively versus $7.1 \%$ and $0 \%$ among acne patients with normal vitamin D (Table 1).

Also, there was statistically significant relationship between the mean level of vitamin$\mathrm{D}$ and grade of acne vulgaris among the studied 
group, where the mean serum vitamin D level was the lowest among patients with 4th grade acne (5.2 \pm 1.7 ) (Table 2). After vitamin D supplementation, there was significant improvement in acne grading where about $60 \%$ of acne patients treated with vitamin D supplementation reached stage zero of acne versus $9 \%$ among those treated with topical treatments only without supplementations. Also no patients treated with vitamin D supplementation have acne grade III or IV versus $9 \%$ of those treated only with topical treatments still have acne stage III (Table 3).

\section{Discussion:}

The results of this study revealed increased frequency of vitamin D deficiency among the studied acne patients (82.5\%). This comes in accordance with a study conducted in Turkey ${ }^{(15)}$ where prevalence of vitamin D deficiency was 95.3\% among 43 acne patients. Lim et al (16) study in Southeast Asia reported that the prevalence of vitamin D deficiency was significantly higher among patients with acne $(48.8 \%)$ in comparison to healthy controls (22.5 $\%)$.

Further support for these results showed by recent studies conducted in Egypt ${ }^{(17)}$ and in Saudi Arabia (18) on acne patients versus matched healthy controls and reported that Serum levels of 25-hydroxy-vitamin D was significantly lower in acne patients than in healthy control. The same results were obtained from Elmohsen et al study (19) which was performed on 60 Egyptian acne vulgaris patients and 30 healthy controls and found significantly lower serum levels of vitamin D in acne patients than in the healthy controls. These findings from different studies indicate that there is a significant relation between vitamin D levels and acne vulgaris and this is contributed to the potent anti-inflammatory effect of vitamin D. However, a cross-sectional study ${ }^{(20)}$ conducted on 714 Kuwaiti adolescents showed no significant association between $25-\mathrm{OH}-\mathrm{Vitamin}$ D level and clinically assessed acne vulgaris.

This study reported increased frequency of vitamin $D$ deficiency among female acne patients $(98 \%$ - p value $<0.001)$ in comparison to males. A study in Italy ${ }^{(21)}$ investigated the impact of gender difference on vitamin D and they found that female gender was associated with severe vitamin D deficiency (41.9\% vs. $30.4 \%, p<0.001)$. However, a study conducted on adult Saudi population found that males had a higher prevalence of vitamin D deficiency $(72.0 \%$ vs. $64.0 \%)$ when compared to female participants and Puspita et al study ${ }^{(23)}$ conducted in Indonesia reported higher mean serum vitamin D level in females $(18.5 \mathrm{ng} / \mathrm{mL})$ than males $(16.68 \mathrm{ng} / \mathrm{mL})$.

This difference may be attributed to the increased prevalence of obesity among Egyptian females in comparison to males according to WHO report ${ }^{(24)}$ and since vitamin D is a fatsoluble vitamin it's highly stored in body fat with low peripheral serum level ${ }^{(22)}$.

As regard the relationship between serum vitamin D level and severity of acne vulgaris; 
this study revealed that $27.3 \%$ and $9.1 \%$ of vitamin D deficient group had grade $3 \& 4$ acne respectively and the mean vitamin $\mathrm{D}$ level was the lowest among patients with 4th grade acne (5.2 \pm 1.7$)$. In accordance with this finding, Lim et al study ${ }^{(16)}$ done on 80 acne patients showed that the level of serum vitamin D was inversely associated with the severity of acne, and there was a significant negative correlation with inflammatory lesions.

Furthermore, a cross sectional study (25) conducted on 60 Sudanese patients suffering from acne vulgaris showed significant decrease in serum vitamin D levels with the increase in acne grading, where the mean vitamin D level was $(16.8 \pm 3.42 \mathrm{ng} / \mathrm{mL})$ among mild acne patients however severe acne cases had the lowest mean vitamin D level $(10.4 \pm 1.64$ $\mathrm{ng} / \mathrm{mL})$.

On the other hand, Alhetheli et al study ${ }^{(18)}$ conducted on Saudi acne patients attending Outpatient Dermatology Clinics at Qassim University Hospital reported that the mean value of vitamin $\mathrm{D}$ was higher in moderate acne $(31.4 \pm 6.9)$ than in mild and severe acne $(26 \pm 9.4$ and 28.4 \pm 6.7 , respectively). However, this difference was not statistically significant. In addition, Toossi et al study ${ }^{(26)}$ conducted on 39 Iranian patients with acne vulgaris, revealed no significant associations between severity of acne and serum vitamin D. This difference may be due to their small sample size.

In the present study there is a significant negative correlation between acne stage and serum level of vitamin D ( $\mathrm{r}=-0.313, \mathrm{P}$ value $<0.05)$. These results are in concordance with a study done ${ }^{(20)}$ in Indonesia which reported a strong negative correlation between serum vitamin D level and acne vulgaris severity $(r=-$ 0,792; $\mathrm{p}<0,05)$. Also, Kemeriz et al study (27) done on 134 acne patients revealed a strong statistically significant negative- correlation between serum vitamin $\mathrm{D}$ levels and acne severity $(r=-.910 ; P<0.001)$.

A significant improvement in acne grading after vitamin D supplementation for two months was the most important finding in the current study where about $61 \%$ of treated patients with vitamin $\mathrm{D}$ and regular acne treatments reached grade 0 of acne vulgaris. This comes in agreement with Lim et al study ${ }^{(16)}$ conducted in Korea that proved significant improvement in inflammatory lesions after supplementation of vitamin D 1000 IU/day for 2 months for acne patients with vitamin $\mathrm{D}$ deficiency where significant improvement and down grading of acne lesion were noted. Mohamed et al ${ }^{(17)}$ study in Egypt reported improved acne and significant higher serum level of vitamin D among cases treated with vitamin D supplementation compared to placebo group.

In contrast to these findings, Tehrani et al study ${ }^{(28)}$ conducted in Iran on 80 women with acne and polycystic ovaries (PCO) treated with metformin and vitamin D for 4 months found no significant effect of vitamin D supplementation on acne lesions. This may be attributed to the 
prevalent hyperandrogenism and increased comedogenesis among PCO female patients.

Conclusion: There's significant relation between vitamin-D deficiency and severity of acne vulgaris. Treatment of acne vulgaris with vitamin D supplementation to vitamin D deficient patients will give better results than topical treatments only. So, it is recommended to evaluate the serum level of vitamin $\mathrm{D}$ in acne patients and provide vitamin D supplementation to vitamin D deficient patients beside topical treatments for acne.

Acknowledgement: sincere gratitude to all patients participated in the study.

Fund: this research received no specific grant from any funding agency in the public or commercial sectors.

Conflict of interest: there is no conflict of interest.

\section{References:}

1. Titus $\mathrm{S}$ and Hodge J. Diagnosis and Treatment of Acne. Am Fam. physician 2012 Oct; 86(8):734-740.

2. Hassan R, Nofal A, Hussien N. Prevalence and Risk Factors of Acne Vulgaris in Adolescents in Belbis City, Sharkia Governorate, Egypt: A Cross-Sectional Study. Egyptian Family Medicine Journal; EFMJ; May 2019, Vol .3(1).

3. Han X, Oon H, Goh L. Epidemiology of post-adolescence acne and adolescence acne in Singapore: a 10-year retrospective and comparative study . J Eur Acad Dermatol Venereol, 2016 Oct; 30(10):1790-1793.
4. Hazarika N. and Archana M. The Psychosocial Impact of Acne Vulgaris. Indian J Dermatol. 2016 Sep-Oct; 61(5): $515-520$.

5. Makrantonaki E, Zouboulis C. An update on the role of sebaceous gland in pathogenesis of acne. Dermatol Endocrinol 2011; 3(1); 41-9.

6. Tanghetti E. The role of inflammation in the pathology of acne. J Clin Aesthet Dermatoln 2013; 6:27-35.

7. Bowe W, Logan A. Dietary fat, fibre, and acne vulgaris. J Am Acad Dermatol 2007; 57:1092-3.

8. Lee W, Choi Y, Sohn M. Expression of inflammatory biomarkers from cultured sebocytes was influenced by treatment with vitamin D”. Indian J Dermatol 2013; 58:327-329.

9. Mostafa W and Hegazy R. Vitamin D and the Skin: Focus on a Complex Relationship: A Review. J Adv Res 2015; 6(6):793-804.

10. Ghodsi S, Orawa S, Christos C. Prevalence, Severity, and Risk Factors of Acne in High School Pupils: A Community-Based Study. $\mathrm{J}$ of investigative dermatology 2009; 129(9):2136-2141.

11. Melnik, B. Acne vulgaris. Role of diet. Der Hautarzt; Zeitschrift fur Dermatologie, Venerologie, und verwandte Gebiete 2010; 61(2): 115-25.

12. Tutakne M, Chari K. Acne, rosacea and perioral dermatitis. Dermatology 2003; 2:689-710 
13. Ringe J, and Kipshoven C, Vitamin Dinsufficiency; an estimate of the situation in Germany. Dermatoendocrinol. 2012; 4(1): 72-80.

14. Rusin`ska A, Płudowski P, Walczak M, Borszewska-Kornacka MK, Bossowski A, et al. Vitamin D Supplementation Guidelines for General Population and Groups at Risk of Vitamin D Deficiency in Poland- Recommendations of the Polish Society of Pediatric Endocrinology and Diabetes and the Expert Panel with Participation of National Specialist Consultants and Representatives of Scientific Societies-2018 Update . Front. Endocrinol. 2018; 9:246.

15. Yildizgören M, Togral A. Preliminary evidence for vitamin $\mathrm{D}$ deficiency in nodulocystic acne, Dermato-Endocrinology 2014; 6:1, e983687, DOI: 10.4161/ derm. 29799.

16. Lim S, Ha J, Lee Y, Seo Y, Im M, Comparison of Vitamin D Levels in Patients with and without Acne: A Case-Control Study Combined with a Randomized Controlled Trial. PLoS One. 2016; 25; 11(8).

17. Mohamed A , Salah E , Abdelaziz R, Abdalla H, El Hanafi H. Hussain G. “The impact of active vitamin $\mathrm{D}$ administration on the clinical outcomes of acne vulgaris . J Dermatolog Treat 2020; 39 (3): 273-7.

18. Alhetheli,G, Abd Elneam A. E, Alsenaid,A, Al-Dhubaibi M. Vitamin D
Levels in Patients with and without Acne and Its Relation to Acne Severity: A CaseControl Study . Clin Cosmet Investig Dermatol. 2020; 13: 759-765.

19. Elmohsen A, Abd El-Aziz M, Abo Mohamed N, Dabash F. Assessment of Serum Level of 25-Hydroxy Vitamin D in Patients with Acne Vulgaris. The Egyptian journal of hospital medidcine.2019; 76(3):3678-3683.

20. AL Taiar A. Akhabbaz M, Alsabah R. Plasma 25-Hydroxy Vitamin D is not associated with Acne Vulgaris. Nutrients 2018; 10 (10):1525.

21. Verdoia M, Schaffer A, Barbieri L. Impact of gender difference on vitamin D status and its relationship with the extent of coronary artery disease. Asian journal of clinical nutrition 2017; 9:1-5

22. Al Quaiz A, Kazi, A., Fouda, M. et al. Age and gender differences in the prevalence and correlates of vitamin D deficiency. Arch Osteoporos 13, 49 (2018).

23. Puspita F. Simanungkalit R, Yosi A. Correlation between Serum 25Hydroxyvitamin D levels with Acne Vulgaris Severity. J Invest Dermatol jan 2020; 129(9):2136-41.

24. World health organization (WHO). Egypt health profile 2015/WHO. Regional office for the Eastern Mediterranean p. WHOEM/HST/225/E, 2015.

25. Taha N, Alfadil G. Serum 25-Hydroxy Vitamin D Levels among Adults Patients 
with Acne Vulgaris in khartoum state http://repository.sustech.edu/handle/123456 789/22663; Nov; 2018.

26. Toossi P,

Azizian Z Yavari H Fakhim T, Enamzade R. Serum 25-hydroxy vitamin D levels in patients with acne vulgaris and its association with disease severity. Clin Cases Miner Bone Metab. Sep-Dec 2015; 12(3):238-42.

27. Kemeriz F, Tuncer S, Acar E, Tuğrul B. Evaluation of 25-hydroxy vitamin D levels and disease severity in patients with acne vulgaris. Dermatol Ther 2020 May; 33(3):e13393.

28. Tehrani H, Mostajeran F, Shahsavari S. The effect of calcium and vitamin D supplementation on menstrual cycle, body mass index and hyperandrogenism state of women with poly cystic ovarian syndrome. J Res Med Sci 2014 Sep; 19(9):875-80.

Table (1): Relationship between Serum Vitamin D and Grading of Acne Vulgaris among the Studied Group

\begin{tabular}{|c|c|c|c|c|c|c|c|c|}
\hline \multirow[t]{2}{*}{ Acne stage } & \multicolumn{2}{|c|}{$\begin{array}{c}\text { Vitamin D } \\
\text { deficiency } \\
\text { group }\end{array}$} & \multicolumn{2}{|c|}{$\begin{array}{c}\text { Normal } \\
\text { vitamin D } \\
\text { Group }\end{array}$} & \multicolumn{2}{|c|}{ Total } & \multirow[t]{2}{*}{$\mathbf{X}^{2}$} & \multirow[t]{2}{*}{$P$ value } \\
\hline & $\mathrm{N}(66)$ & $\%$ & $\mathrm{~N}(14)$ & $\%$ & $\mathrm{~N}(80)$ & $\%$ & & \\
\hline - Grade 1 & 18 & 27.3 & 9 & 64.3 & 27 & 33.8 & 8.1 & 0.043 \\
\hline - Grade II & 24 & 36.4 & 4 & 28.6 & 28 & 35 & & \\
\hline - $\quad$ Grade III & 18 & 27.3 & 1 & 7.1 & 19 & 23.8 & & \\
\hline - Grade IV & 6 & 9.1 & 0 & 0 & 6 & 7.5 & & \\
\hline
\end{tabular}


Table (2): Serum Vitamin D Level and Severity of Acne Vulgaris

\begin{tabular}{|c|c|c|c|c|c|c|}
\hline & $\begin{array}{c}\text { Grade I } \\
\text { N } 27\end{array}$ & $\begin{array}{c}\text { Grade II } \\
\text { N } 28\end{array}$ & $\begin{array}{c}\text { Grade III } \\
\text { N } 19\end{array}$ & $\begin{array}{c}\text { Grade IV } \\
\text { N } 6\end{array}$ & F test & O value \\
\hline Vit D & $\begin{array}{c}15.8 \pm 4 \\
9-32\end{array}$ & $\begin{array}{c}11.02 \pm 6.6 \\
8.5-25\end{array}$ & $\begin{array}{c}8.2 \pm 2.9 \\
3-15\end{array}$ & $\begin{array}{l}5.2 \pm 1.7 \\
2.7-7.5\end{array}$ & 7.6 & $<0.001$ \\
\hline
\end{tabular}

Table (3): Grading of Acne Vulgaris among Both Groups at the End of Follow-up Period

\begin{tabular}{|l|c|c|c|c|c|c|}
\hline $\begin{array}{c}\text { Acne } \\
\text { grade }\end{array}$ & \multicolumn{2}{|c|}{$\begin{array}{c}\text { Group I with } \\
\text { Vitamin D } \\
\text { supplementation }\end{array}$} & \multicolumn{2}{|c|}{$\begin{array}{c}\text { Group II without } \\
\text { Vitamin D } \\
\text { supplementation }\end{array}$} & $\mathbf{X}^{2}$ & P value $^{2}$ \\
\cline { 2 - 6 } & $\mathrm{N}=33$ & $\%$ & $\mathrm{~N}=33$ & $\%$ & & \\
\hline I & 20 & 60.6 & 3 & 9.1 & 39.8 & $<0.001$ \\
II & 12 & 36.4 & 16 & 48.5 & & \\
III & 1 & 3 & 11 & 33.3 & & \\
IV & 0 & 0 & 3 & 0.1 & & \\
\hline
\end{tabular}




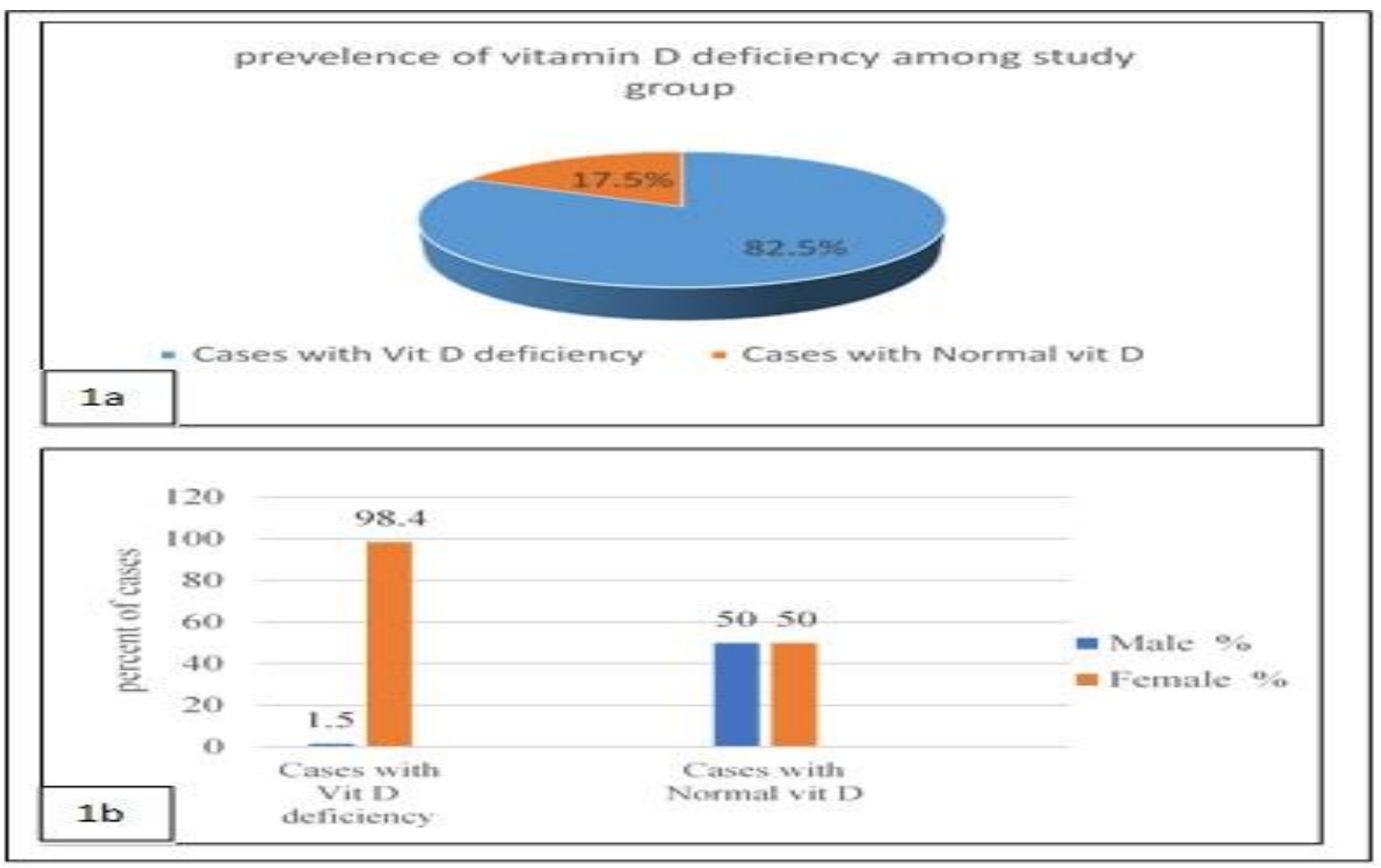

Figure (1): Prevalence of Vitamin D Deficiency Among Study Group (1a), Vitamin Deficiency among Male and Female Acne Patients (1b)

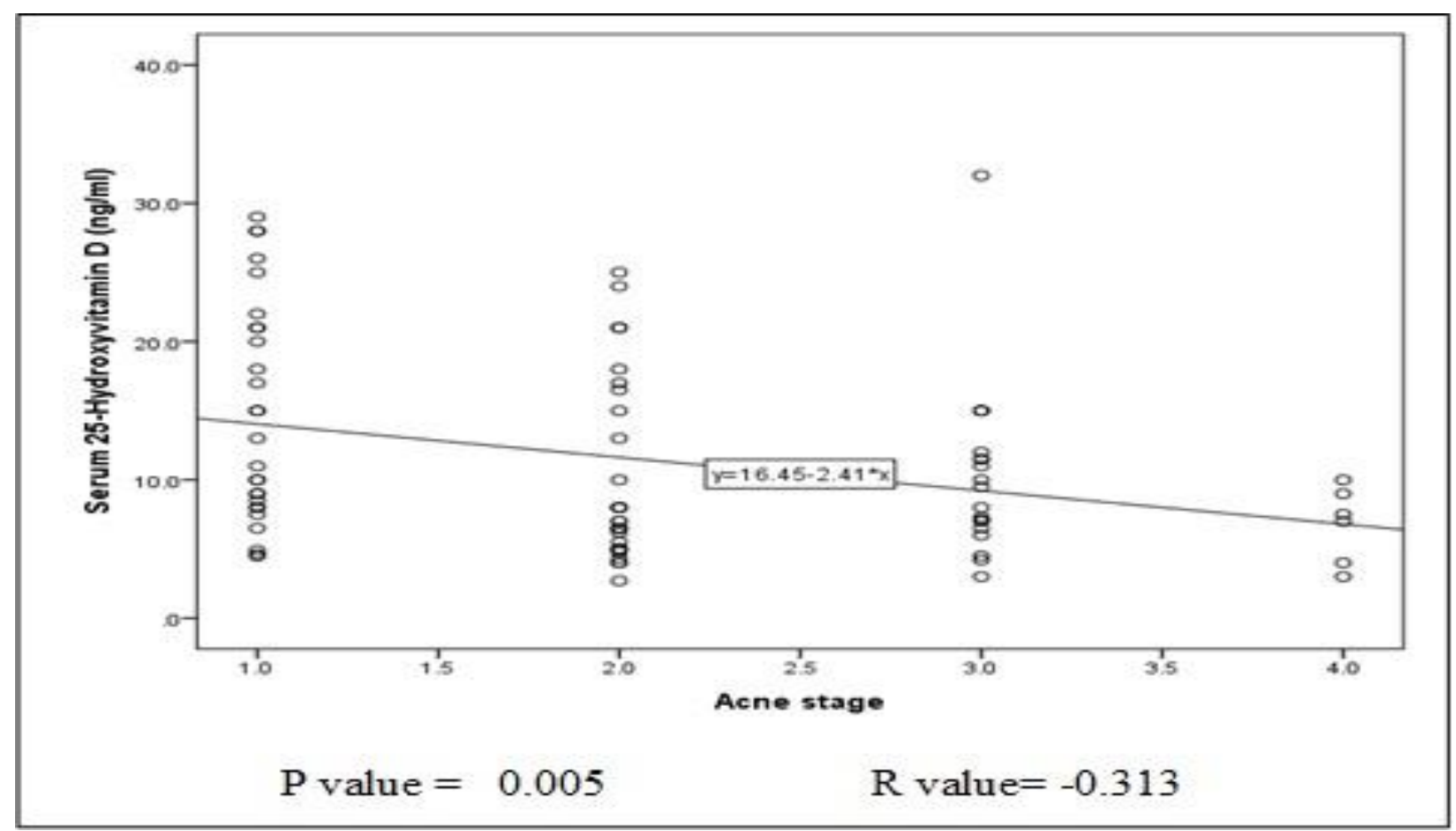

Figure (2): Correlation between Acne Grade and Serum Level of Vitamin D 
Figure (3a): A case of grade II acne vul garis where there are multiple comedones, few papules and a pustule after treatment with topical acne treatments and oral vit D 2000IU for two months; the patient downgraded to grade 0 where there's no comedones or papules only post inflammatory hyperpigmentation is found.
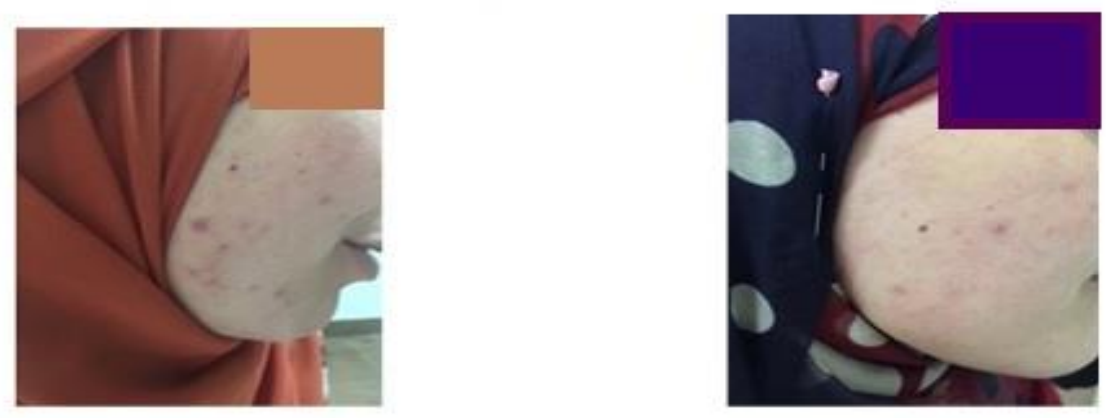

Figure (3b): A case of grade II acne vulgaris where there's multiple comedones, a papule and a pustule treated with topical treatment for acne for two months and downgraded to grade I acne where there's remaining comedones and macules
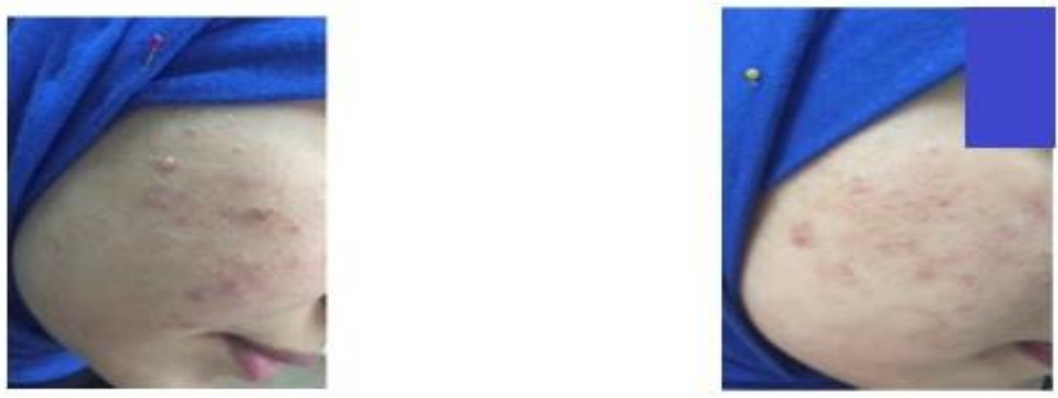

\section{Figure (3): Acne Vulgaris Improvement with Different Treatment Protocols}

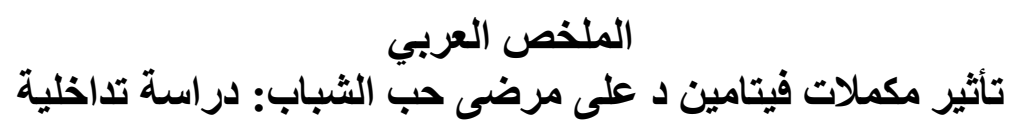

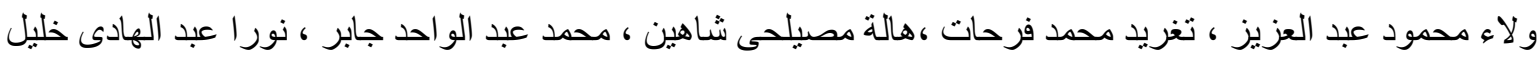

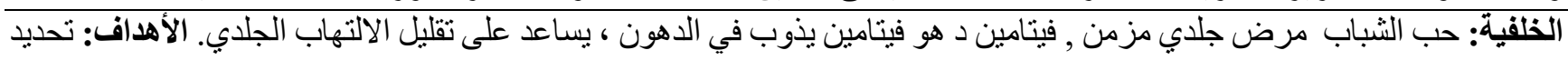
تأثير استعمال فيتامين (د) على تحسين درجة حب الثباب ـ الطريقة: دراسة حالة أجريت على 80 مريضاً بحب الثباب في عبادة الجلدية بالمستشفى الجامعي. 66 من 80 مريضا يعانون من نقص فيتامين د. تم توفير حبوب من فيتامين د د 2000 وحدة دولية لكل

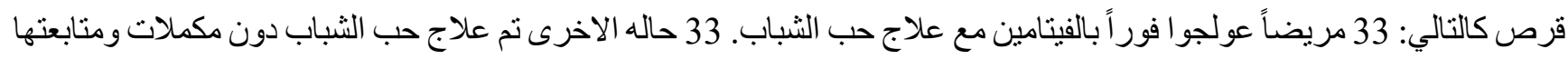
سريريا لمدة شهرين ثم تم اعطاء فيتامين دعن طريق الفم لدو اعى اخلاقيه ـ النتائج: هناك علاقة كبيره بين مستوى فيتامين د ودرجة

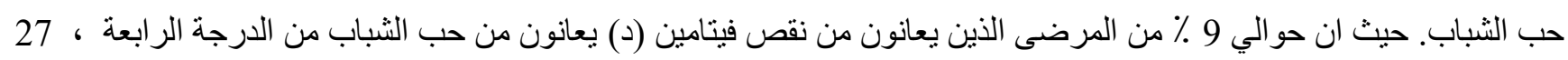

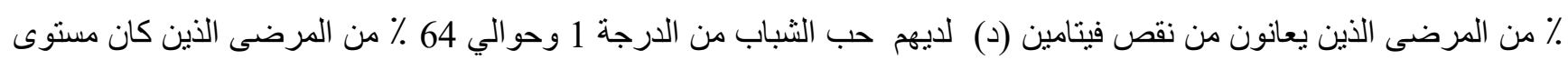
فيتامين د لديهم طبيعي كانو ا يعانون من حب الثباب من الدرجة 1. كما كان هناك تغير كبير في درجة حب الثباب بعد العلاج بفيتامين د: حيث وصل حو الي 35٪ من مرضى حب الثباب الذين يعانون من نقص فيتامين د إلى المستوى صفرمن حب الثباب ـ الخلاصة: يفضل إعطاء فيتامين (د) عن طريق الفم في علاج حب الثباب للمرضى الذين يعانون نقص فيتامين د للحصول على نتائج أفضل. 